\title{
Training Offers in Greece Fostering e-Competencies
}

\author{
Aliki Panagiotarou and Yannis C. Stamatiou \\ University of Patras \\ Patras, Greece
}

\begin{abstract}
This paper presents the findings of a study of Greek training programs targeting e-competencies that are on demand in the Greek labour market. This study is an effort to identify, categorize, and understand the content of ICT training programs in Greece. To obtain qualitative and quantitative raw data for our study, we collected information from publicly available information from the programs' websites and descriptions of studies during the period April 2017 November 2017. We find 201 training programs in the field of ICT and we construct a table according to the following criteria: Training providers, focus area, training methods, duration of the programs, previous experience in ICT, certification and e-skills that were obtained. In our results will try to present preliminary findings why Greece have low digital skills and provide recommendations as a part of conclusion that can help close the digital gap in Greece.
\end{abstract}

Keywords: Training programs; e-competencies; ICT skills; adult education; e-learning.

\section{Introduction}

The development of e-skills and e-competencies has been shown to contribute to a large extend to increasing individuals' advantage in the ICT labour sectors as well as to play a key role in strengthening competitiveness, innovation and social cohesion in the European economy (Giotopoulos at al, 2017),(Korte at al, 2014),(Martin, 2018) Moreover, e-skills and e-competencies have a strong potential to influence positively competitiveness and innovation (OECD, 2016, 2018; Ananiadou \& Claro, 2009).

Over the last years, the number of ICT jobs has been growing at a faster rate than any other job category and the employment rate of ICT professionals have grown more than $3 \%$ per year over for past 10 years) (DIGITALEUROPE, 2016). Europe needs skilled ICT in order to fill job vacancies in the expanding digital economy and satisfy the needs society providing training programs is a crucial in preparing people to complement and enhance their e-skills meeting today's employment challenges. 
At the same time as Greece's difficult position regarding lifelong learning there is a gap of Digital Performance in Greece shown by the Digital Economy and Society Index (DESI) (European Commission, 2017). Especially with regard to Human Capital is calculated as the average of Basic Skills and Usage and Advanced Skills and Development (European Commission, 2018). Considering the Human Capital indicator index, Greece has one of the last positions throughout Europe (DESI, 2018)

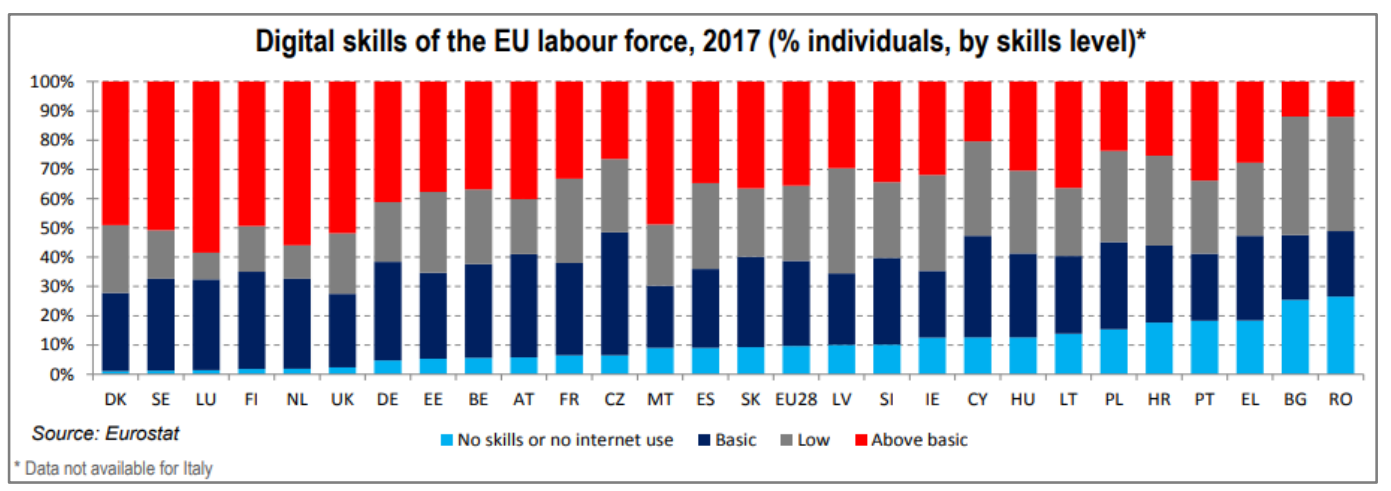

Figure 1. Desi Report 2018-Human Capital

In order to help in this direction, our work targeted several of the strongest lifelong learning and continuing education programs in order to survey the professional education landscape in Greece as well as to identify its strengths and weaknesses.

The paper is organized as follows: In Section 2 we give a brief overview of the EU and the National (Greek) Policies for ICT skills development. Section 3 studies the methodologies and characteristics of the Greek educational programs that target these sectors. The study's results, along with comparisons among the programs, are discussed in Section 4. Finally, in Section 5 we present our conclusions and propose directions for future work.

\section{Literature Review}

In this section we focus on the following two tasks: (i) Provide frameworks and tools for digital literacy in terms of New Skills Agenda for Europe (Europe Commission, 2016) and recommended actions for the ICT adoption in Greece (Tsakanikas at al, 2014). Additionally, we mention several European and international ICT players providing recognized ICT training schemes and certifications (European Commission, 2016)

\subsection{The Digital agenda for Europe and Greece}

EU Policy for lifelong learning in ICTs

One of the priorities in the New Skills Agenda for Europe is to reduce the Digital Skills Gap in order to strengthen EU citizens' digital competence through appropriately designed training programs. To this end, the European Commission has produced several reports on good practices and 
recommendations in order to improve their curricula and training methodologies (European Commission, 2017)

A number of initiatives have been taken to simplify the transparency and recognition of skills across Europe (Panitsides, Griva \& Chostelidou, 2012). These initiatives include the following (Kraatz, 2016): 1) The European Qualifications framework, 2) The Europass qualification presentation documents, 3) The European Credit system for Vocational Education and Training, 4) The European Quality Assurance Reference Framework, 5) The European Digital Competence Framework for Citizens, and 6) The European eCompetence Framework (e-CF).

All these recommended frameworks and actions can form a basis for establishing a quality assurance mechanism for ICT training and skill enhancing programs that can be of use by policy makers and ICT stakeholders alike.

\subsection{National Lifelong learning Policies in the ICT area}

Human factor is the driving force for the development of digital economy in Greek society. One of the top priorities of the National Digital Strategy 2016-2021 in Greece is the development of lifelong education programs for enhancing digital skills for citizens. Additionally, a set of actions can be taken such as the following: a) The development of Massive Open Online Courses (MOOCs) in ICT, b) The collaboration with the Hellenic Information Technology \& Communications Association, i.e. the Hellenic Network of Professionals of Informatics, the local chambers and the Greek Manpower Employment Organization [OAED] for the creation of a series of seminars for the development of specialized ICT skills, c) Offering access to training seminars that lead to certifications d) Supporting and expanding ICT education for public servants (Ministry of Digital Policy, 2016)

\subsection{A brief survey of the Greek continuing education landscape}

A variety of training service providers offers programs for enhancing digital skills in people with digital skills and non-digital skills. Many of these programs target ICT skills and are designed in collaboration with institutions related to Greece's workforce. Firstly there are Vocational Training Centers [KEK] that provides continuous vocational training (Vergidis \& Karalis, 2004). Moreover, there are is a wide range of other adult educational mechanisms such the Greek Manpower Employment Organization [OAED] (Koutidou, 2014) and vocational training targeting the general population, unemployed through the Youth and Lifelong Learning Foundation [INEDIBIM]. Concurrency, the National Organisation for the Certification of Qualifications \& Vocational Guidance [EOPPEP] is an authorized body that assess the quality and reliability of existing lifelong learning programs in Greece while it is, also, responsible for developing the Hellenic Qualifications Framework (HQF), which is linked to the European Qualifications Framework (EQF) (EOPPEP,2016). In particular, EQF targets quality assurance in VET programs based on well-established European standards and specifications.

At the same time, many universities, technological institutes, and business schools across Greece design ICT-oriented continuous education programs 
based on curricula that are particularly suited to adult trainees and professionals. The content and learning outcomes of these training are proposed by established educational institutions of Greece such as the ones discussed above.

\subsection{Initiatives offered by the ICT industry}

Many ICT organizations have developed industry-based e-skill certification programs that are globally recognized. These educational programs concerns at development digital skills to all levels. The European Commission has connected all these ICT organizations with stakeholders and interested parties in order to help citizenship improve digital skills (Digital Europe, 2016). In Table 1 we can see some of the most popular global vendor's initiatives in offering ICT training and certification programs in IT sectors that already appear in the Greek ICT employment landscape.

Table 1. Global vendor's initiatives in Greek landscape

\begin{tabular}{|c|c|}
\hline $\begin{array}{c}\text { Industry-based certification in } \\
\text { ICT areas }\end{array}$ & Offered curriculum \\
\hline TUV Austria Academy & $\begin{array}{l}\text { Data Protection Officer, Social Media \&Ads, } \\
\text { Certified E-commerce Consultant (CEC) }\end{array}$ \\
\hline ECDL & Computer Essentials, Word Processing, IT Security \\
\hline Cisco Learning Network & CCNA, CCNP, CISSP, CompTIA \\
\hline $\begin{array}{ll}\text { International } & \text { Personnel } \\
\text { Certification Association, (IPC) }\end{array}$ & Digital Marketing, Sales professionals \\
\hline Digital Marketing Institute (DMI) & Digital Marketing \\
\hline $\begin{array}{l}\text { Aristotle Certification Training and } \\
\text { Assessment (ACTA) }\end{array}$ & $\begin{array}{l}\text { Certified E-Commerce Consultant, Certified } \\
\text { Internet Marketing Professional, Certified Sales } \\
\text { Professional, Certified Project Manager }\end{array}$ \\
\hline Pearson VUE & $\begin{array}{l}\text { Certiport, Acclaim, GED Testing Service, PTE } \\
\text { Professional }\end{array}$ \\
\hline American Concrete Institute (ASI) & $\begin{array}{l}\text { Educational \& training programs, certification } \\
\text { programs in IT area. }\end{array}$ \\
\hline PSI & Digital Literacy, IT Skills, In-Application Testing \\
\hline OMCP & $\begin{array}{l}\text { On line Marketing Certified Professional (OMCP), } \\
\text { On line Marketing Certified Associate (OMCA) }\end{array}$ \\
\hline VWmare IT Academy & $\begin{array}{llll}\text { Cloud } & \text { Fundamentals, } & \text { Digital } & \text { Business } \\
\text { Transformation } & & \\
\end{array}$ \\
\hline Microsoft Imagine Academy & $\begin{array}{l}\text { Computer Science, IT infrastructure, Data Science, } \\
\text { Productivity. }\end{array}$ \\
\hline Oracle Academy & $\begin{array}{lcc}\text { Database Design, } & \text { Programming, } & \text { Java } \\
\text { Fundamentals and Java Programming } & \\
\end{array}$ \\
\hline Google & $\begin{array}{l}\text { Advanced Android Development and Android } \\
\text { Developer Fundamentals }\end{array}$ \\
\hline AXELOS & $\begin{array}{l}\text { ITIL (IT Service Management), PRINCE2 (Project } \\
\text { Management), MOP (Portfolio Management) }\end{array}$ \\
\hline $\begin{array}{l}\text { The International Association of } \\
\text { Innovation Professionals (IAOIP) } \\
\text { Academy }\end{array}$ & Certified Professional Innovator (CPI) \\
\hline PeopleCert & Software Developer \\
\hline
\end{tabular}




\section{Our survey - Methodology}

The goal of our survey was to map the current lifelong training landscape in the domain of e-skills and e-competencies enhancement. To this end, we first formed a list of Greek training program with an ICT focus that we would survey in depth based on information found on their websites as well as program content

\subsection{Objectives}

The main objectives of our survey are the following questions: Which are the basic issues of Greek Training programs as concerns ICT training? What is the impact of the current EU Lifelong learning policy in the Greek Landscape? Are Greek training programs oriented of these EU policy documents content? Why is Greece occupying one of the lowest positions in digital skills? What could change in terms of adult education in digital skills? We will try to give preliminary answers to the above questions mapping basic characteristics in training programs.

\subsection{Data gathering and analysis variables}

After forming the list of targeted institutions and programs, we started the online data gathering process. We identified the relevant, to our goals, information by analyzing every information item and data entry on the program's information pages as well as their content descriptions. This process lasted from April 2017 until November 2017.

One of the first results of our analysis at this first stage was that the targeted programs and lifelong education initiatives can be categorized into 8 distinct groups based on the following axes: Type of Training Provider, Focus Area of the program, Training Methods deployed, Duration of the program, Instruction Language, Whether Certification is provided, Whether Previous Experience in ICT is required, Whether Learning outcomes of the modules are explicitly stated. Our analysis categorized a total of 201 training programs (the full data is available in the supplementary material). The categorization criteria, for each axis, are shown in Figure 2. 


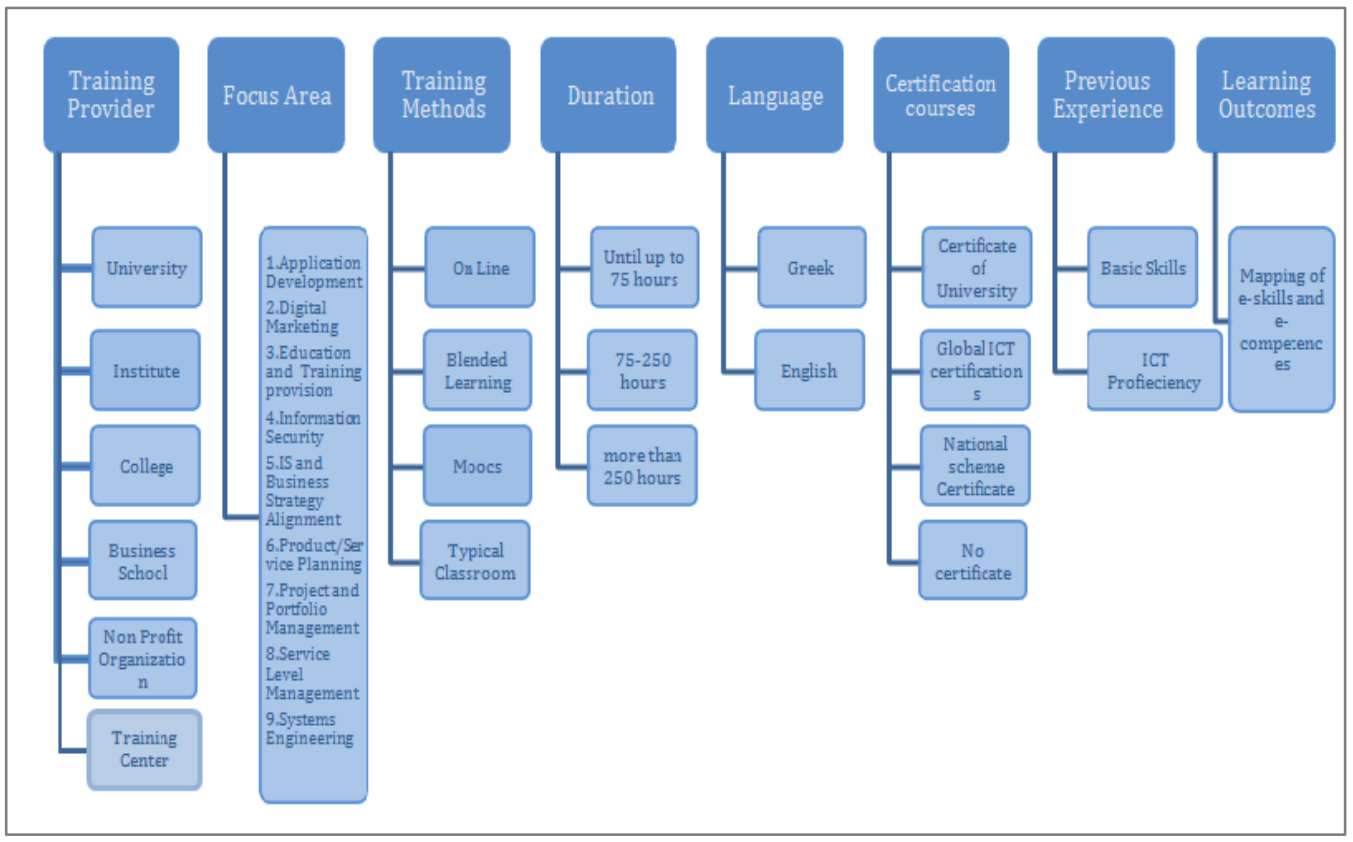

Figure 2. Design of groups of the table

The criteria are discussed below in full.

- Training provider: We considered Universities, Institutes, Colleges, Business Schools, Training Centers and Non Profit Organizations.

- Focus Area: Focus on e-CF focus areas

$\checkmark$ Application Development: It includes Web Design based on different software tools such as Joomla, WordPress, Dreamweaver and Web Visibility. In addition, it includes Game Development with Unity 3D, Web Development, Cloud Computing, Advanced Microsoft Excel 2013, Android Mobile Development, Database Administration, Data Centers, Processing data with the R language, Computer Programming etc.

$\checkmark$ Digital Marketing: This includes Search Engine based Marketing-Search engine optimization/ Pay per click SEM (SEO/PPC), Mobile Marketing, Business Analytics, Social Media and Digital Marketing, Google Adwords in tourism enterprises, TripAdvisor as a Marketing Tool for Hotel Businesses, E-mail Marketing \& Marketing Automations, Digital tools to increase sales, and Microsoft Office Publisher.

$\checkmark$ Education and Training provision: This includes programming as learning activity with the Scratch environment, the exploitation of WEB 2.0 tools in the contemporary school, Hellenic Literature and Digital Technologies, Blended Learning and E-learning Instructors' Education.

$\checkmark$ Information Security: This includes Official (ISC) ${ }^{2}$ CBK Training Seminars for the CISSP®, Information Security management Systems, Data Protection Officer training, Certified Ethical Hacking, compliance with GDPR etc.

$\checkmark$ IS (Information Systems) and Business Strategy Alignment: This includes Applied Business Administration in Simulation Environments, Developing business actions through Web and social media, Advanced Business Management, Business Information Systems, Certified e-Commerce 
Consultant, Innovation Manager, and Business Analysis Body of Knowledge (BABOK).

$\checkmark$ Product/Service Planning: This is training leading to the title of a Certified Product Manager.

$\checkmark$ Project and Portfolio Management: This includes Advanced Project Management - Professional Education as MS Project, PRINCE2 and Vellum Certified IT Project Management

$\checkmark$ Service Level Management: Training on Service Level Management.

$\checkmark$ Systems Engineering: This includes Network Engineering, CCNA (Cisco Certified Network Associate) Routing and Switching, Informatics Sciences, CCNA-ICND1, Cisco Certified Network Professional (CCNP), CCNA Security, Hardware Installation, Software, Networks and Network Security etc.

- Training methods: This includes Typical Classroom or Distant Learning as elearning, MOOCs and Blended learning.

- Duration: Considering the Greek legislation (3369/2005), long term lifelong learning programs lead to the following certifications:

1) A program up to 75 hours in total, leads to a Training Certificate.

2) A program from more than 75 hours and up to 250 hours, leads to a Lifelong Learning Certificate.

- Language: This characterizes the language of the seminars (Greek or English).

- Certification courses: This classifies programs according to the accreditation body

- Previous Experience: This category classifies the trainees' profiles as Basic digital skills and proficiency digital skills.

- Learning outcomes: Clear statement of the learning outcomes of the programs with respect to the targeted e-skills and e-competencies.

Based on these criteria, in the next section we provide the qualitative and quantitative results of our analysis of the 201 programs we considered.

\section{Analysis of Data}

Our analysis is focused in the following groups: a)Focus Area b)Training providers c)Training methods and d)Duration vs training methods. All of those are analyzed in the below subsections.

\subsection{Focus Area}

This criterion is related to the targeted e-competencies and the learning outcomes of the studied programs.

Table 2 shows that the majority of the 201 ICT training programs are focused on Application Development (50.50\%) and Digital Marketing (18.32\%). We should remark that we encountered a course that was offered by two collaborating training program providers (this appears as program number 52 in the supplementary material). 
Table 2. Count of training programs in focus area

\begin{tabular}{|l|c|r|}
\hline \multicolumn{1}{|c|}{ Focus Area } & $\begin{array}{c}\text { Count of Training } \\
\text { programs }\end{array}$ & \% of Total \\
\hline Application Development & 102 & $50.50 \%$ \\
\hline Digital marketing & 37 & $18.32 \%$ \\
\hline Education and Training Provision & 6 & $2.97 \%$ \\
\hline Information Security Management & 6 & $2.97 \%$ \\
\hline IS and Business Strategy Alignment & 15 & $7.43 \%$ \\
\hline Product/Service Planning & 3 & $1.49 \%$ \\
\hline Project and Portfolio Management & 12 & $5.94 \%$ \\
\hline Service Level Management & 3 & $1.49 \%$ \\
\hline Systems Engineering & 18 & $8.91 \%$ \\
\hline Grand Total & $\mathbf{2 0 2}$ & $\mathbf{1 0 0 . 0 0 \%}$ \\
\hline
\end{tabular}

In some more detail, from the 201 offered programs, $102(50.50 \%)$ are focused on Application Development. and 37 programs (18.32\%) were focused on Digital Marketing

\subsection{Training providers}

The training providers cover a wide span of activity sectors as shown in the following bar graph (Figure 3).

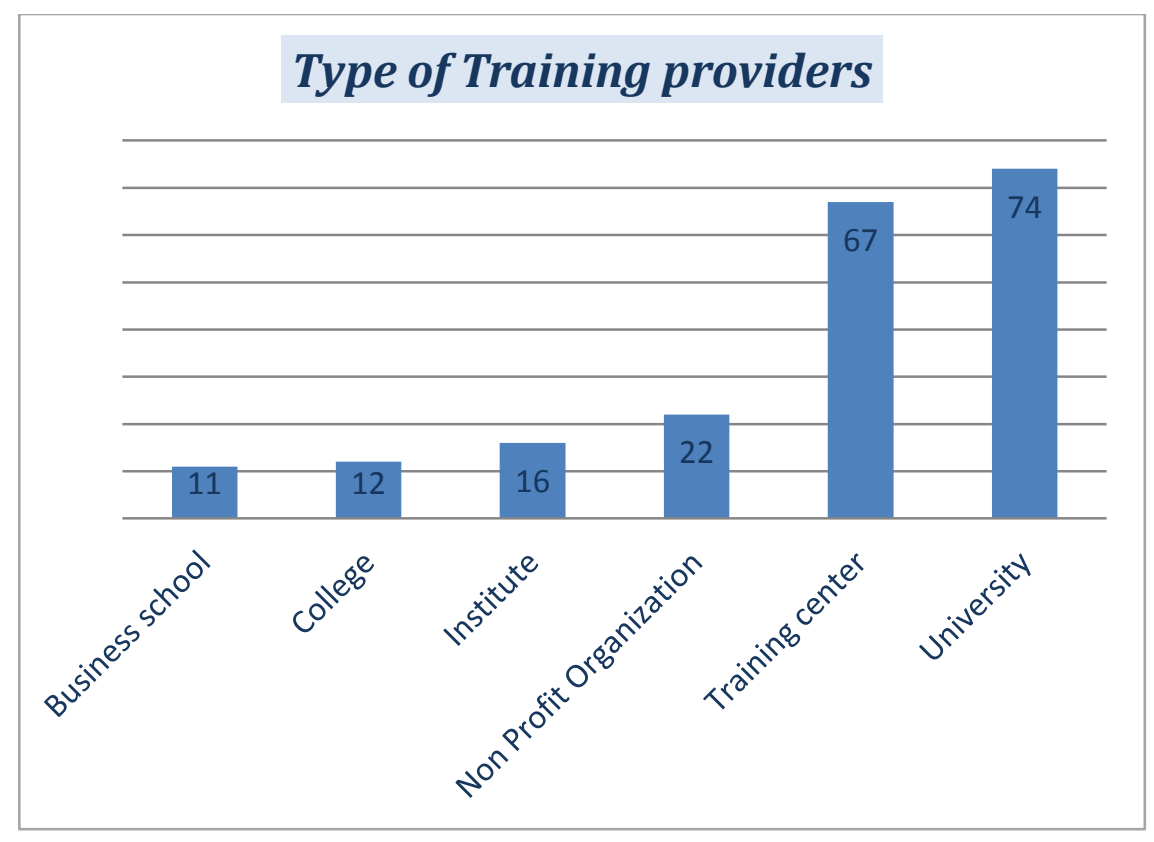

Figure 3. Count of offered training programs by type of training providers

We see the majority of training programs offered by Universities (74) and Training Centers (67). Next are Non-profit organizations (22), Institutes (16), Business schools (11) and Colleges (12). 


\subsection{Training methods}

As we see in the Figure 4, there were 95 online seminars, 96 typical classroom seminars, 4 blended learning programs and 5 MOOCs based seminars.

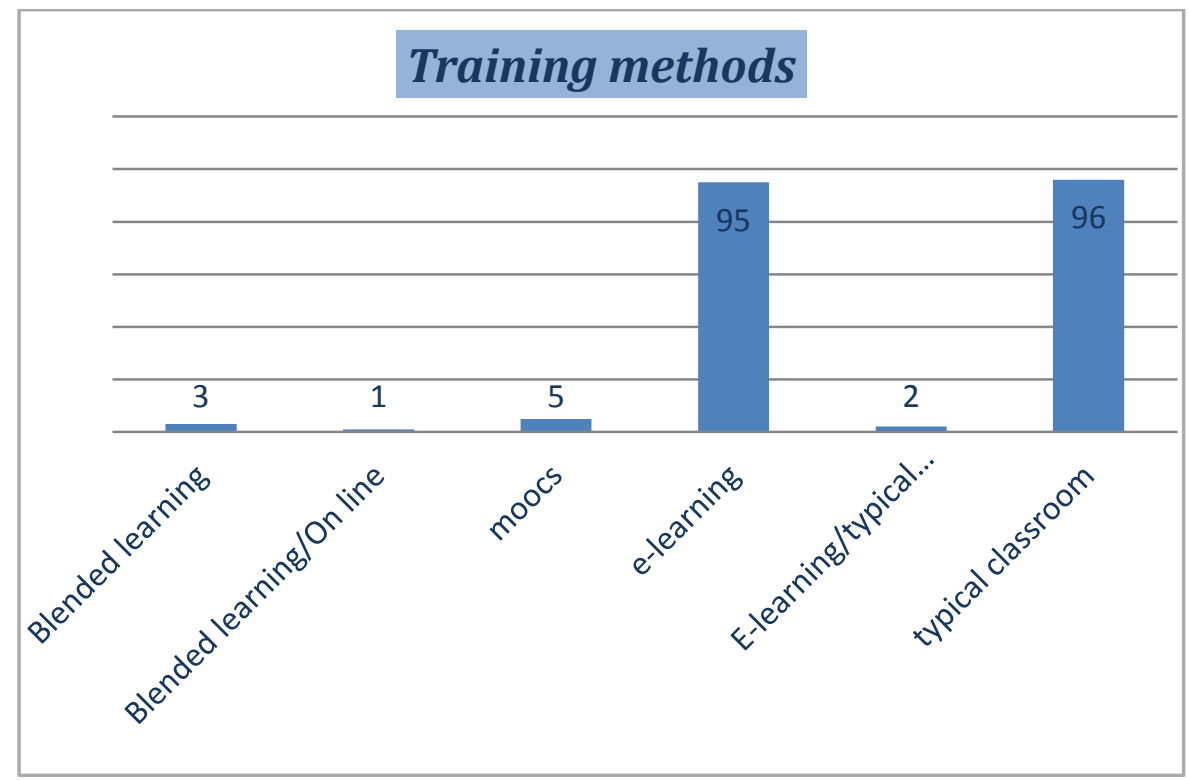

Figure 4. Count of offered training programs by training methods

\subsection{Duration vs. Training methods}

One interesting goal of our analysis was to examine database is the amount of the offered online and typical classroom seminars in relation to duration of these. Our sample of 201 programs includes 72 typical classroom programs and 67 online seminars with the duration up to 75 hours. Also, there are 24 online and 5 typical classroom programs with duration more than 75 hours and up to 250 hours. Finally, we identified 4 blended learning programs and 4 programs organized around a MOOC platform. 


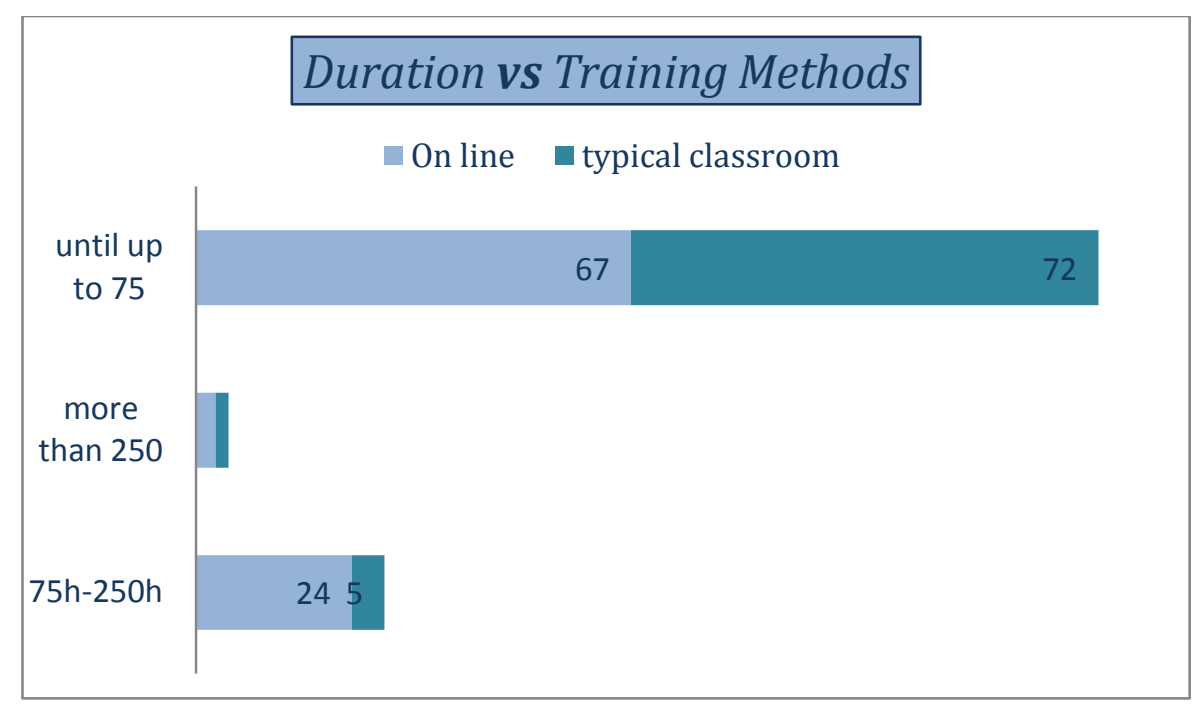

Figure 5. Count of offered training programs by Duration and Training Methods

\section{Good practices in respecting the EU e-skills agenda and other global standards}

In this section, we present some good practices that we feel are promising in developing programs that can play a crucial role in digital skills development in Greece. These good practices are based on recommendations set by the EU agenda for Digital Skills as well as recognized global standards and certifications.

\subsection{E-learning in Athens}

The e-Learning Center of the National and Kapodistrian University of Athens [EKPA] is active since 2001 providing vocational training and other training programs linking theory and academia with the skills and applied knowledge sought in the corresponding professional fields.

This training center follows good practices, certified by a number of European, national and global quality labels. All offered programs are designed with a focus on the knowledge and skills required in employment landscape of Greece as well as at an international level. The programs are offered, exclusively, through e-learning, offering to the trainees a flexible time scheduling due to the lack of obligation for physical presence. The successful completion of a Vocational Education and Training program leads to the Qualified Training or Conformance Certificate.

The e-learning Program of the University of Athens' Education and Lifelong Learning Center has adopted all the European policies and tools that have been developed in the framework of the "Education and Training Strategy for 2020" (Education and Training 2020 Strategy). Also, it complies with the European Qualifications Framework, including ECVET, EQAVET, Management Certification Quality System in accordance with "ELOT EN ISO 9001: 2008", Certificate of Quality Management System from the International Certification Network (IQNET), which provides an international passport for global 
recognition and market access (IQNET ISO 9001: 2008 Certificate), EOPPEP, and the Certification of Educational Platform and educational content (EKPA, 2001).

We identified 33 training programs which focus on fostering e-skills.

\subsection{Coursity}

Coursity is an innovative platform that hosts seminars that take place online in the form of MOOCs. This platform was designed by the University of Ioannina and supports online learning in the form of video tutorials.

The online courses cover a wide range of scientific fields as well as cognitive subjects and last for 4-8 weeks. The course coordinators and teachers are recognized professors of Greek Universities.

Successful attendance of the seminars leads to the award of a Certificate from the Association of Lifelong Learning Centers of Greek Universities.

Coursity gives to everyone the opportunity to access high-quality learning resources while it gives the opportunity of attending multiple courses free of charge. It offers eight training programs in total but only two training programs for advanced digital skills. (Coursity). In the same concept there is another MOOC platform called Mathesis that was designed by The University Publications of Crete and Stavros Niarchos Foundation Cultural Center in 2008. It offers twenty two training programs in total and only two concerns of ICT seminars (Mathesis, 2008). These web platforms have the potential to play a key role in transforming the training program landscape in Greece through MOOCs Learning.

\subsection{OTE Academy training centre}

The OTE Academy, which is a member of the OTE Group (one of the Greek telephony service providers), is one of the largest professional training organizations in Greece, providing innovative educational services that contribute to the professional and personal development of the trainees. It offers a large number of training programs that adopt international learning schemes and certifications.

With OTE Academy's main business activity, OTE Academy designs and implements high-level ICT training programs. OTE Academy is a certified training partner for the largest international organizations and technology institutes such as Cisco, Alcatel - Lucent Enterprise, Oracle, Microsoft and is an official test center of Pearson Vue's largest international certification organization.

We identified 22 training programs which were advertised on the official Web site of the center (OTE Academy)

\subsection{HEPIS}

HEPIS is a non-profit organization whose goal is the development of skills in the ICT domain. It provides many learning activities towards digital and social skills enhancement. It is, also, a member of the Council of European Professional Informatics Societies (CEPIS) that promotes the development of the Information Society across Europe (HEPIS, 2006) 


\section{Conclusion}

In Greece, [EOPPEP] is the principal agency for the accreditation and quality assurance of lifelong learning programs offered by training providers such as training centers, Universities and Technological Institutes, Business schools and others, which need a common frame of reference for the development training programs oriented to digital skills and competencies enhancement. This framework should be developed at European or national level in particular as regards content orientation in digital skills.

The policy actions that described in Literature review provide the appropriate framework for a large number of training providers initiatives that address the development of digital skills. In particular, the curricula must align with policy recommendations and with labour market needs.

In Greece, the number of training seminars focused on ICT literacy is, rather, small while the training syllabus we studied are rather general and not welldefined except in some cases that follow good practices or offer some global ICT industry training and certification. Moreover, there are a small amount of initiatives by training centers carrying well-recognized program certification labels. The implementation of recommended actions related to the Digital Strategy of Greece and the EU Digital Policy, is expected to help Greece assess strengths and weaknesses of its training strategies which are focused on fostering digital skills. More specifically, are expected to provide the appropriate frameworks and tools that will support adult education interventions and will lead to a reconsideration of the targeted domains through, for instance, redefining priorities in Digital Economy, planning, design and delivery of training syllabus in citizenship education, workplace education and training, towards improving digital skills and competencies. The use of frameworks like DigComp and e-CF could provide excellent good practices as guidance for the Greek ICT training programs and generally in European cities that are at a low level in terms of digital skills.

However, one possible direction for the immediate future could be the development of a detailed reference framework that could form the basis for training schemes in the ICT domain. This framework could provide on methodologies and curricula for developing digital skills and competencies, models for assessment and self-assessment, as well as certification of digital skills. In addition, the framework could provide examples of learning outcomes, good practices, and directions for teaching, learning and assessment.

The framework could emerge from a common initiative among all training providers, such as the ones which we studied, and [EOPPEP], which can provide a systematic way of monitoring and benchmarking all the programs and their outcomes with respect to how well the trainees shave developed e-skills and ecompetencies.

Naturally, further research is required in order to develop and validate this common framework and to monitor its applicability in Greece, for the ICT domain. This research can be based on the literature we reviewed in this paper as well as the findings of our research (see, also, the detailed supplemental file). 
Nevertheless, Furthermore, new technologies and new learning tools with Webbased learning approaches, such as MOOCs (there is a notable shortage of moocs), could make training programs to more trainees across Greece, building a realistic and widely acceptable plan for further digital competencies development.

Finally, the training program providers that have been studied in the context of our work can be conducted (e.g. by [EOPPEP]) in order to relay their valuable teaching and program development experiences towards a successful, market needs oriented, approach that suits best the requirements of today's digital economy. This approach will assist all training programs providers in Greece and other European countries have low levels in digital skills to redefine their instruction and learning evaluation models, and redesign their programs accordingly. At the same time, the proposed approach can be used to evaluate the training value of the offered training programs, in relation to the real needs of the ICT job market, to understand the profiles of participants as well as their motivations behind their choices to attend a training program. We believe that the supplementary data we have gathered for accompanying this paper contain information that may help along all these proposed courses of action.

\section{References}

Ananiadou, K. and M. Claro (2009), "21st Century Skills and Competences for New Millennium Learners in OECD Countries", OECD Education Working Papers, No. 41, OECD Publishing, Paris. https://doi.org/10.1787/218525261154.

CEDEFOP. (2006).ICT skills certification in Europe-Cedefop Dossier series; 13 . [PDF File] Retrieved from https://www.cedefop.europa.eu/files/etv/Upload/Information_resources/Bo okshop/431/6013_en.pdf

Coursity. (n.d.). Coursity. Retrieved 6 10, 2018, from https://coursity.gr/

DIGITALEUROPE (2016) DIGITALEUROPE AND THE EC'S SKILLS STRATEGY 2016 [Policy Statement] Retrieved from https://www.digitaleurope.org/resources/DIGITALEUROPE-Position-paperon-Digital-Skills/

Digital Europe. (2016, June 10). Grand Coalition. Retrieved from http://www.digitaleurope.org/Our-Work/Projects/DSJCoalition

e-learning of national and Kapostrian University of Athens. (2001). e-learning. Retrieved 612 , 2018, from https://elearn.elke.uoa.gr/sxetika.html

EOPPEP (2016). Greece EQF Referencing Report. Retrieved from https:/ / ec.europa.eu/ploteus/sites/eac-eqf/files/Greece _EQF_Referencing_Report.pdf.

European Commission. (2017). Digital Single Market. Retrieved 3 27, 2017, from DESI: https://ec.europa.eu/digital-single-market/en/desi

European Commission. (2018). Digital Single Market. Retrieved 1 28, 2018, from Digital Agenda Scoreboard: https://ec.europa.eu/digital-single-market/en/downloadscoreboard-reports

European Commission. (2018).-Human Capital-Digital Inclusion and Skills. Retrieved from http://ec.europa.eu/newsroom/dae/document.cfm?doc_id=52247 
European Commission (2016) A New Skills Agenda for Europe. Retrieved from https://cor.europa.eu/en/engage/studies/Documents/New-Skills-AgendaEurope.pdf. doi:10.2863/708323

European Commission (2016). DigComp 2.0: The Digital Competence Framework for Citizens. Update Phase 1: The Conceptual Reference Model. Luxembourg: Office for Official Publications of the European Communities.

European Commission. (2017). Europe Digital Progress report: Luxemburg, 2017. Retrieved from http:/ / ec.europa.eu/newsroom/document.cfm?doc_id=45188

Giotopoulos, I., Kontolaimou, A., Korra, E., \& Tsakanikas, A. (2017). What drives ICT adoption by SMEs? Evidence from a large-scale survey in Greece. Journal of Business Research, 81, 60-69. doi:10.1016/j.jbusres.2017.08.007

HEPIS. (2006). HEPIS. Retrieved 6 17, 2018, from https:/ / www.hepis.org/the-body/

KARALIS, T., \& VERGIDIS, D. (2004). 'Lifelong education in Greece: recent developments and current trends. International Journal of Lifelong Education, 23(2), 179-189. doi:10.1080/0260137042000184200

Koutidou, E. (2014). European Union and Greek lifelong learning policy within an intercultural context: preliminary insights from research in the Sociology of Law. International Journal of Lifelong Education, 33(3), 309-325. doi:10.1080/02601370.2014.891889

Kraatz, S. (2016). NEW SKILLS AGENDA FOR EUROPE:THE ROLE OF LIFELONG GUIDANCE POLICIES. Euroguidance Conference. Lisbon: Policy Department for Economic and Scientific Policies.

Korte, Werner \& Hüsing, Tobias \& Gareis, Karsten. (2014). e-Skills for Jobs in Europe Measuring Progress and Moving Ahead. doi:10.13140/2.1.1739.9044

Martin J, 2018."Skills for the 21st Century: Findings and Policy Lessons from the OECD Survey of Adult Skills," Working Papers 201803, Geary Institute, University College Dublin.

Mathesis. (2008, February). Mathesis. Retrieved 10 20, 2018, from https://mathesis.cup.gr/

Ministry of Digital Policy, T. a. (2016). GR_Digital_Strategy. Athens , 2016. .[PDF File] Retrieved from http://www.mindigital.gr/index.php

OECD (2016), "Skills for a Digital World: 2016 Ministerial Meeting on the Digital Economy Background Report", OECD Digital Economy Papers, No. 250, OECD Publishing, Paris, https://doi.org/10.1787/5jlwz83z3wnw-en

OECD (2018). The future of Education and skills, [Policy Statement]. Retrieved from https://www.oecd.org/education/2030/E2030\%20Position\%20Paper\%20(05.04. 2018).pdf

OECD (2019), "ICT skills in the workplace", in Measuring the Digital Transformation: A Roadmap for the Future, OECD Publishing, Paris, doi:org/10.1787/32f9bc83-en

OTE Academy. (n.d.). OTE Academy. Retrieved 6 10, 2018, from https://oteacademy.gr/el/page/about-us/

Panitsides, E, Griva, E. \& Chostelidou, D (2012). European Union Policies on Lifelong Learning: Inbetween competiveness enchancement and social stability reinforcement. Procedia Social and Behavioral Sciences WCES, 46(46), 548-553 . doi: 10.1016/j.sbspro.2012.05.158

Tsakanikas, Danchev, S., Giotopoulos, I., Korra, E., \& Pavlou, G. (2014, December). ICT Adoption and Digital Growth. Retrieved 1 10, 2018, from http://www.capital.gr/Content/RelatedFiles/45/453b22d941634943b670ee448c 5bc9ce.pdf 